\title{
Research on The Impact of Business Environment on China's Industrial Upgrading
}

\author{
Fu Wenyu ${ }^{1, *}$, Zhao Jingfeng ${ }^{2}$ \\ ${ }^{1}$ School of Economics and Management, Northwest University, Xi'an, Shaanxi, China \\ ${ }^{2}$ Research Center of Western China’s Economic Development, Northwest University, Xi'an, Shaanxi, China
}

Keywords: Business environment; Industrial upgrading; Influencing factors; Empirical research

\begin{abstract}
Using panel data of China's 30 provinces from 2004 to 2018, this paper empirically analyzes the impact of business environment on industrial upgrading and its regional heterogeneity. The conclusions are as follows: Firstly, the business environment has a significant positive impact on industrial upgrading both at the overall level and sub-regional level. Secondly, at the subregional level, business environment has a greater impact on industrial upgrading in the central region than that in the eastern and western regions. Finally, business environment plays a role in industrial upgrading together with other factors, innovation output level, foreign direct investment and fiscal expenditure have different effects on industrial upgrading in different regions. Therefore, all regions should improve the business environment and formulate industrial policies in line with their own development, so as to promote the optimization and upgrading of industrial structure.
\end{abstract}

\section{Introduction}

With the deepening of economic system reform, China's industrial structure has shown a trend of increasing economic ties among regions and industries, expanding cooperation scale and fields, and accelerating the pace of industrial transformation and upgrading. However, the problems of unbalanced industrial structure, low industrial quality and more complex industrial development have not been fundamentally solved. Therefore, it is necessary to take effective measures to speed up the adjustment of industrial structure and promote the coordinated and sustainable development of the three industries. As an important embodiment of economic soft power, business environment is the core content of improving the quality of industrial development, and improving business environment is a crucial link in the process of industrial upgrading.

According to the World Bank's doing business report 2019, the business environment of Chinese mainland ranks 46th out of 190 economies. Although the ranking is up significantly from last year, as the second largest economy in the world, China's business environment still needs further improvement. In recent years, the central government has attached great importance to building a better and more attractive business environment. Strengthening the construction of business environment is not only conducive to the gathering of talents, funds and other elements in the region, but also conducive to improving the regional economic innovation and competitiveness. Under the background of the new era, improving China's business environment is of great practical significance for accelerating industrial development and building a modern industrial system.

Nowadays, the business environment is crucial to the development of a country or region. This term is derived from the "Doing Business" project conducted by the International Finance Corporation of the World Bank Group, which published the "Doing Business" report. Most scholars have discussed the factors influencing the business environment and its economic and social effects [1-3]. More and more research shows that the business environment has a profound impact on the economic and social development of a country, especially developing countries. In addition, the research field of industrial upgrading has been relatively mature, most scholars discuss the measurement of industrial upgrading and its influencing factors [4,5].

To sum up, although there are many researches on business environment and industrial upgrading, few papers can study the relationship between business environment and industrial 
upgrading. In addition, limited by the availability of data or the purpose of research, most researches only conduct simple qualitative analysis, while the empirical analysis on the impact of business environment on industrial upgrading is almost at a blank stage. Therefore, this paper will use the panel data of 30 provinces in China from 2004 to 2018 to empirically analyze the impact of business environment on industrial upgrading, and conduct regional heterogeneity test in the eastern, central and western regions, so as to provide reference for improving business environment and promoting industrial structure optimization and upgrading in each region.

\section{Research Design}

\subsection{Model}

First of all, we use factor analysis method to calculate the composite index of business environment ( $B E$ ) of 30 provinces in China from 2004 to 2018, and then explore the impact of business environment on industrial upgrading. The basic model is as follows:

$$
\text { Structure }_{\mathrm{it}}=\alpha_{0}+\alpha_{1} B E_{i t}+\varepsilon_{i t}
$$

In model (1), Structure represents the upgrading of industrial structure, $B E$ represents the business environment, $i$ represents region, t represents year. Considering the influence of the lag term of explained variable, the first-order lag term of explained variable is introduced into the model for corresponding estimation. In addition, other factors affecting industrial upgrading are added, such as innovation output level, foreign direct investment and fiscal expenditure are taken as control variables, thus the model (2) is obtained:

$$
\text { Structure }_{\mathrm{it}}=\beta_{0}+\beta_{1} \text { Structure }_{i(t-1)}+\beta_{2} B E_{i t}+\beta_{3} C \mathrm{X}_{i t}+\beta_{4} F D I_{i t}+\beta_{5} G O V_{i t}+v_{i t}
$$

In model (2), Structure refers to the upgrading of the industrial structure, expressed by the advanced index of industrial structure. $B E$ represents the business environment of the region, $C X$ represents the level of innovative output, FDI represents foreign direct investment, and GOV represents fiscal expenditure, $i$ represents region, trepresents year, and $v$ represents random disturbance term.

\subsection{Data description and source}

The upgrading of industrial structure ( Structure ). We use the advanced index of industrial structure to measure the upgrading of industrial structure [6]. This index is expressed by the ratio of output value of the tertiary industry and output value of the secondary industry, it can fully reflect the process of the gradual servitization of the industrial structure. The higher the value is, the higher the industrial structure is.

The construction of the business environment index ( $B E)$. There are many index systems of business environment. Among them, the index system used in the business environment report issued by the World Bank is comprehensive and scientific. However, the update speed of the data is slow and the index system does not match the actual situation of China. Therefore, based on the availability of data and the actual situation of China's business environment construction, this paper draws on the practice of other scholars to integrate the economic basic environment, international environment, legal environment and green development environment into the index system ${ }^{[7]}$, including five secondary indexes (see Table 1). Here, the indexes are processed in a consistent and dimensionless way, and then the comprehensive index of business environment of each province from 2004 to 2018 is obtained by factor analysis using SPSS software (see Table 2). Through the analysis, we find that the business environment in China has obvious regional heterogeneity. Among them, the business environment in Shanghai, Beijing, Tianjin, Jiangsu, Zhejiang, Guangdong, Fujian, Shandong, Liaoning and Chongqing is better than the national average. The business environment in Inner Mongolia, Hubei, Jilin, Henan, Anhui, Hebei, Hunan, Heilongjiang, Sichuan, Jiangxi, Hainan, Shaanxi and Guangxi is general, while that is poor in Shanxi, Ningxia, Yunnan, Xinjiang, Guizhou, Gansu and Qinghai. It can also be seen that most provinces with good 
business environment are located in the eastern region of China, while the business environment in the central and western regions is generally worse.

The control variable group. $C X$ reflects the innovation output level of the region, which is represented by the number of patent application. FDI refers to foreign direct investment, which is represented by the per capital foreign direct investment. Gov represents the financial expenditure, which is measured by the ratio of government expenditure to GDP.

Considering the availability and comparability of data, this paper uses the relevant data of 30 provinces in China from 2004 to 2018 for analysis. In the process of research, we smooth the variable data. Most of the original data come from the China Statistical Yearbook, the statistical yearbooks of provinces, and the statistical database of China's economic and social development.

Table 1 Construction of business environment index system.

\begin{tabular}{|c|c|c|c|}
\hline \multirow{6}{*}{$\begin{array}{l}\text { Business } \\
\text { environment }\end{array}$} & Primary indexes & Secondary indexes & Data description \\
\hline & \multirow[b]{2}{*}{$\begin{array}{l}\text { Economic basic } \\
\text { environment }\end{array}$} & Per capital GDP & $\begin{array}{c}\text { Adjustment according to per } \\
\text { capital GDP index }\end{array}$ \\
\hline & & Urbanization rate & $\begin{array}{c}\text { The ratio of urban } \\
\text { population to total } \\
\text { population }\end{array}$ \\
\hline & $\begin{array}{l}\text { International } \\
\text { environment }\end{array}$ & Dependence on foreign trade & $\begin{array}{l}\text { The ratio of imports and } \\
\text { exports to GDP }\end{array}$ \\
\hline & Legal environment & $\begin{array}{c}\text { Development of market } \\
\text { intermediary organizations and } \\
\text { environmental scoring of legal } \\
\text { system }\end{array}$ & $\begin{array}{l}\text { Convert to cross-year } \\
\text { comparisons }\end{array}$ \\
\hline & $\begin{array}{l}\text { Green development } \\
\text { environment }\end{array}$ & $\begin{array}{l}\text { Discharge intensity of industrial } \\
\text { waste water }\end{array}$ & $\begin{array}{c}\text { The ratio of industrial waste } \\
\text { water discharge to industrial } \\
\text { added value }\end{array}$ \\
\hline
\end{tabular}

Table 2 Business environment of 30 provinces in China from 2004 to 2018.

\begin{tabular}{|c|c|c|}
\hline Better business environment & General business environment & Poor business environment \\
\hline & Inner Mongolia (8.7888) & \\
Shanghai (16.5106) & Hubei (8.5517) & \\
Beijing (15.5365) & Jilin (8.4105) & Shanxi (6.8704) \\
Tianjin (14.5348) & Henan (8.0478) & Ningxia (6.6511) \\
Jiangsu (13.6480) & Anhui (7.9459) & Yunnan (5.9608) \\
Zhejiang (13.3346) & Hebei (7.8782) & Xinjiang (5.8152) \\
Guangdong (12.8698) & Hunan (7.7397) & Guizhou (5.4163) \\
Fujian (10.6979) & Heilongjiang (7.6774) & Gansu (5.0428) \\
Shandong (10.6699) & Sichuan (7.6580) & Qinghai (4.9922) \\
Liaoning (10.0380) & Jiangxi (7.5306) & \\
Chongqing (9.0576) & Hainan (7.3185) & \\
& Shaanxi (7.2744) & \\
& Guangxi (7.0490) & \\
\hline
\end{tabular}

Note: the average value of the composite business environment index for each region from 2004 to 2018 is shown in brackets.

\section{Analysis and Test of Empirical Results}

In order to test the robustness of regression results and explore the explanatory power of each variable, this paper conducts regression at the overall level and sub-regional level. The empirical results after eliminating the heteroscedasticity of the model are shown in Table 3 and Table 4.

\subsection{Analysis of empirical results}

As can be seen from the regression results in Table 3, at the overall level, the regression 
coefficient of business environment ( $B E$ ) is significantly positive, indicating that the business environment can promote the upgrading of China's industrial structure. In regression result 3 , the coefficient of business environment is 0.0096, and it is statistically significant at the $1 \%$ level, indicating that when the business environment index increases by $1 \%$, the industrial advanced index increases by $0.96 \%$. That is to say, the better the business environment, the better the transformation and upgrading of China's industrial structure. As can be seen from regression results at the subregional level in Table 4, the impact of business environment ( $B E$ ) is significantly positive in all regions. In regression result 5, regression result 7 and regression result 9, the influence coefficients of business environment on industrial upgrading in eastern, central and western regions are 0.0075 , 0.0254 and 0.0126 , and all of them pass the significance test of $10 \%$. At the same time, it can also be concluded that the coefficient of business environment in the central region is larger than that in the eastern and western regions, which shows that strengthening the construction of business environment in the central region has a more obvious effect on industrial upgrading of the region.

In addition, the business environment and other factors play a role in industrial upgrading. In terms of other factors: From the overall perspective, the impact of innovation output level and financial expenditure on industrial upgrading in China is significantly positive, with coefficients of 0.0094 and 0.3423 , and both of them through the test of significance. It shows that innovation output level and fiscal expenditure have a positive effect on industrial upgrading, and the coefficient of fiscal expenditure is lager, which shows that the role of government investment in industrial upgrading process is crucial. The impact of FDI is negative (-0.1212), but not significant. From the sub-regional perspective, other factors have different effects on different regions. For the eastern region, the level of innovation output plays a prominent role in promoting industrial upgrading. For the central region, the influence of government financial expenditure is great. For the western region, innovation and fiscal expenditure are very important for the upgrading of regional industrial structure. The specific analysis is as follows.

The impact of innovation output level $(C X)$ on industrial upgrading is significantly positive at the overall level and in the eastern and western regions, which is consistent with the research conclusions of most scholars. It can be seen from the economic development history that technological innovation has a great influence on the evolution of industrial structure, and a lot of practices have proved the importance of innovation for industrial upgrading. However, in the process of research in the central region, innovation output level has a negative impact, which may be due to the disputation of the rationality and representativeness of the factor represented by the number of patent applications, and there is certain time lag in innovation output, so the effectiveness and conversion rate of patent application in production practice are low.

The impact of foreign direct investment (FDI) is negative at the overall level and in the central and western regions, while that in the eastern regions is positive, but not significant. This is because the effect of foreign investment on industrial upgrading will be affected by other factors, for example, the intermediate product demand of foreign companies and a series of complex consequences. If only foreign direct investment is considered, and the technological gap between the host country and the investing country is not considered, the influence of foreign direct investment will be uncertain.

The impact of fiscal expenditure ( $G O V$ ) is significantly positive at the overall level and subregional level, indicating that expansion of fiscal expenditure can promote the upgrading of industrial structure. In fact, the increase of national fiscal expenditure will guide the investment behavior of enterprises and have a positive impact on industrial transformation and development. Expanding fiscal expenditure not only provides financial support, but also increases public goods needed for industrial upgrading, which will help improve the market environment, reduce transaction costs, improve the allocation and use efficiency of production factors, form a strong industrial agglomeration effect, and promote the optimization and upgrading of industrial structure. 
Table 3 Regression results at the overall level

\begin{tabular}{|c|c|c|c|}
\hline Variable & Regression result 1 & Regression result 2 & Regression result 3 \\
\hline $\mathrm{BE}$ & $\begin{array}{c}0.0486 * * * \\
(0.0046)\end{array}$ & $\begin{array}{c}0.0069 * * * \\
(0.0015)\end{array}$ & $\begin{array}{c}0.0096 * * * \\
(0.0036)\end{array}$ \\
\hline Structure $(-1)$ & & $\begin{array}{c}0.9792 * * * \\
(0.0153)\end{array}$ & $\begin{array}{c}0.9624 * * * \\
(0.0165)\end{array}$ \\
\hline $\mathrm{CX}$ & & & $\begin{array}{l}0.0094 * \\
(0.0051) \\
\end{array}$ \\
\hline FDI & & & $\begin{array}{l}-0.0212 \\
(0.0207) \\
\end{array}$ \\
\hline GOV & & & $\begin{array}{c}0.3423^{* * *} \\
(0.0569)\end{array}$ \\
\hline -Cons & $\begin{array}{c}-0.5419 * * * \\
(0.0440)\end{array}$ & $\begin{array}{c}-0.0360 * * \\
(0.0155)\end{array}$ & $\begin{array}{c}-0.2155^{* * *} \\
(0.0369)\end{array}$ \\
\hline $\mathrm{R} 2$ & 0.2120 & 1 & 1 \\
\hline AR (2) & 1 & 0.9275 & 0.9337 \\
\hline $\mathrm{N}$ & 450 & 450 & 450 \\
\hline
\end{tabular}

Note: $* * *, * *, *$ are significant at the level of $1 \%, 5 \%$ and $10 \%$, and the standard error of estimation is in brackets.

Table 4 Regression results at the sub-regional level

\begin{tabular}{|c|c|c|c|c|c|c|}
\hline \multirow[b]{2}{*}{ Variable } & \multicolumn{2}{|c|}{ The eastern region } & \multicolumn{2}{|c|}{ The central region } & \multicolumn{2}{|c|}{ The western region } \\
\hline & $\begin{array}{l}\text { Regression } \\
\text { result } 4\end{array}$ & $\begin{array}{l}\text { Regression } \\
\text { result } 5\end{array}$ & $\begin{array}{l}\text { Regression } \\
\text { result } 6\end{array}$ & $\begin{array}{l}\text { Regression } \\
\text { result } 7\end{array}$ & $\begin{array}{l}\text { Regression } \\
\text { result } 8\end{array}$ & $\begin{array}{c}\text { Regression } \\
\text { result } 9\end{array}$ \\
\hline $\mathrm{BE}$ & $\begin{array}{c}0.0858 * * * \\
(0.0051)\end{array}$ & $\begin{array}{l}0.0075^{*} \\
(0.0074) \\
\end{array}$ & $\begin{array}{c}0.0693 * * * \\
(0.0153)\end{array}$ & $\begin{array}{c}0.0254^{*} \\
(0.1424)\end{array}$ & $\begin{array}{c}0.0362 * * * \\
(0.0099)\end{array}$ & $\begin{array}{c}0.0126 * \\
(0.0071) \\
\end{array}$ \\
\hline Structure (-1) & & $\begin{array}{c}0.7727^{* * *} \\
(0.0514)\end{array}$ & & $\begin{array}{c}0.9351^{* * *} \\
(0.0427)\end{array}$ & & $\begin{array}{c}0.9092 * * * \\
(0.0432)\end{array}$ \\
\hline CX & & $\begin{array}{c}0.0326^{*} \\
(0.0173) \\
\end{array}$ & & $\begin{array}{l}-0.0044 \\
(0.0154) \\
\end{array}$ & & $\begin{array}{c}0.0123^{* *} \\
(0.0057) \\
\end{array}$ \\
\hline FDI & & $\begin{array}{c}0.0167 \\
(0.0249) \\
\end{array}$ & & $\begin{array}{l}-0.4059 \\
(0.3681) \\
\end{array}$ & & $\begin{array}{c}-0.0982 \\
(0.1295) \\
\end{array}$ \\
\hline GOV & & $\begin{array}{c}0.0533 \\
(0.3413)\end{array}$ & & $\begin{array}{c}0.8806^{* * *} \\
(0.2989)\end{array}$ & & $\begin{array}{c}0.3091 * * * \\
(0.0880)\end{array}$ \\
\hline -Cons & $\begin{array}{c}-0.9872 * * * \\
(0.0621)\end{array}$ & $\begin{array}{c}-0.4736 * * * \\
(0.1066)\end{array}$ & $\begin{array}{c}-0.7847 * * * \\
(0.1215)\end{array}$ & $\begin{array}{c}-0.2829 * * * \\
(0.9417)\end{array}$ & $\begin{array}{c}-0.4012 * * * \\
(0.0669)\end{array}$ & $\begin{array}{c}-0.2611^{* * *} \\
(0.0380)\end{array}$ \\
\hline R2 & 0.2059 & 1 & 0.1569 & 1 & 0.1229 & 1 \\
\hline AR (2) & 1 & 0.9609 & 1 & 0.8572 & 1 & 0.7591 \\
\hline $\mathrm{N}$ & 165 & 165 & 120 & 120 & 165 & 165 \\
\hline
\end{tabular}

Note: $* * *, * *, *$ are significant at the level of $1 \%, 5 \%$ and $10 \%$, and the standard error of estimation is in brackets.

\subsection{Robustness test}

In order to verify the reliability of above empirical results, the robustness test is carried out based on data. According to the business environment as shown in Table 2, the research objects are redivided into different regions, and then the corresponding estimates are made to test whether the results are still significant. Table 5 reports the results of robustness test. It can be seen from Table 5 that the influence sign of business environment $(B E)$ is positive in regression result 10 , regression result 11 and regression result 12, which is completely consistent with the corresponding results in Table 3 and Table 4, with a slight difference in significance, indicating that the empirical results are robust. 
Table 5 Robustness test results

\begin{tabular}{|c|c|c|c|}
\hline \multirow{3}{*}{ Variable } & $\begin{array}{c}\text { Better business } \\
\text { environment }\end{array}$ & $\begin{array}{c}\text { General business } \\
\text { environment }\end{array}$ & $\begin{array}{c}\text { Poor business } \\
\text { environment }\end{array}$ \\
\cline { 2 - 4 } & Regression result 10 & Regression result 11 & Regression result 12 \\
\hline \multirow{2}{*}{ BE } & $0.0108^{* *}$ & $0.0205^{* * *}$ & 0.0105 \\
& $(0.0053)$ & $(0.0063)$ & $(0.0171)$ \\
\hline \multirow{2}{*}{ Structure (-1) } & $0.9627^{* * *}$ & $0.9612^{* * *}$ & $0.8050^{* * *}$ \\
& $(0.0023)$ & $(0.0297)$ & $(0.0609)$ \\
\hline \multirow{2}{*}{ CX } & 0.0090 & 0.0042 & $0.0426^{* * *}$ \\
& $(0.0082)$ & $(0.0080)$ & $(0.0143)$ \\
\hline \multirow{2}{*}{ FDI } & -0.0261 & 0.0463 & 0.1784 \\
& $(0.0228)$ & $(0.0556)$ & $0.3162)$ \\
\hline \multirow{2}{*}{ GOV } & $0.4167 * *$ & $0.4021^{* *}$ & $\left(0.1741^{*}\right.$ \\
& $(0.1941)$ & $-0.2673^{* * *}$ & $-0.33144 *$ \\
\hline \multirow{2}{*}{ Cons } & $-0.2429^{* * *}$ & $(0.0527)$ & $(0.1032)$ \\
\hline AR $(2)$ & $(0.0741)$ & 0.9138 & 0.7839 \\
\hline $\mathrm{N}$ & 0.9703 & 195 & 105 \\
\hline
\end{tabular}

Note: $* * *, * *, *$ are significant at the level of $1 \%, 5 \%$ and $10 \%$, and the standard error of estimation is in brackets.

\section{Conclusion and Suggestion}

Based on the panel data of 30 provinces in China from 2004 to 2018, this paper makes an empirical research on the impact of business environment on China's industrial upgrading. The main conclusions are as follows: (1) Both at the overall level and sub-regional level, business environment has a significant positive impact on industrial upgrading, business environment can promote the upgrading of China's industrial structure. (2) At the sub-regional level, business environment has a greater impact on the industrial upgrading in the central region than that in the eastern and western regions, indicating that strengthening of the business environment construction in the central region has a more obvious effect on the industrial upgrading. (3) Business environment plays a role in industrial upgrading together with other factors. Among them, the impact of innovation output level and fiscal expenditure on China's industrial upgrading is significantly positive, while the impact of foreign direct investment is negative, and the effect of each factor has regional heterogeneity.

According to above research conclusions, this paper puts forward some countermeasures and suggestions to accelerate industrial upgrading. On the one hand, we should give full play to the positive role of business environment in China's industrial upgrading and take effective measures to improve business environment. At the present stage, China's high-quality economic development cannot be separated from good business environment. The government should give the approval authority and simplify the process as much as possible, and provide efficient services to high-tech enterprises with strict industrial control, based on the objective reflection of enterprises on business environment in the region. Only a better business environment can attract more high-quality enterprises to enter the region, promote industrial transformation and upgrading, and accelerate the construction of a modern industrial system. On the other hand, the upgrading of industrial structure is affected by regional differences. While improving the business environment, other factors should be fully considered. Therefore, in the process of accelerating the construction of business environment, local governments should pay attention to the core influencing factors according to the actual characteristics of their regions and formulate policies for industrial transformation and upgrading in a scientific and reasonable manner. The eastern region should focus on innovationdriven development and improve the level of scientific and technological innovation. The central region should increase the investment and support to the tertiary industry and play the key role of 
the government in the process of industrial upgrading. The western region should speed up the regional economic construction, strengthen the investment in education, science and technology, promote the optimization and adjustment of industrial structure, so as to achieve catch-up and transcendental development.

\section{Acknowledgement}

Social Science Foundation of Ministry of Education of China (15JJD790025).

\section{References}

[1] Gong, B. Business Environment Construction in Shanghai Free Trade Zone from the Perspective of Internationalization and Rule of Law. Academic Monthly, 2014, 1: 38-44.

[2] Wang, H. Is A Stricter Intellectual Property Protection System Conducive to Technological Innovation? Economic Research, 2011, 2: 124-135.

[3] Zhang, H. The Influence of Regional Business Environment on the Export Trade of Enterprises. Southern Economy, 2017, 10: 75-89.

[4] Lu, Z., Li, S. The Impact of Rural Formal and Informal Financial Development on the Upgrading of Regional Industrial Structure. Financial and Economic Research, 2015, 9: 53-64.

[5] Cai, H., Xu, Y. Does Trade Opening affect the Upgrading of China's Industrial Structure? Quantitative and Technological Economic Research, 2017, 10: 3-22.

[6] Gan, C., Zheng, R., Yu, S. The Impact of Industrial Structure Change on Economic Growth and Fluctuation in China. Economic Research, 2011, 5: 4-17.

[7] Yuan, L., Du, X. Business Environment and Total Factor Productivity of Industry: An Empirical Analysis Based on the Panel Data of Industry in China's Provinces from 1994 to 2014. Journal of Harbin University of Commerce, 2018, 5: 55-67. 